\title{
アクリル繊維の熱安定化処理による密度変化
}

\author{
東京工業大学工学部 高久 明・照井 俊・多賀二十志* \\ 奥居德昌・清水二郎
}

\section{DENSITY CHANGES OF ACRYLIC FIBERS BY THERMAL STABILIZATION}

\author{
By Akira Takaku, Shun Terui, Futoshi Taga*, \\ Norimasa Okui and Jiro Shimizu
}

(Department of Textile and Polymeric Materials, Tokyo Institute of
Technology, O-okayama, Meguro-ku, Tokyo, Japan)

The density changes of acrylic fibers by isothermal stabilization at temperatures from 221 to $281^{\circ} \mathrm{C}$ have been investigated. The density increased with increasing heat treatment time and reached independently of heat treatment temperature a value of about $1.58 \sim 1.60 \mathrm{~g} / \mathrm{cm}^{3}$ at longer heat treatment times. The molecular weight and molecular volume per repeat unit of polymer of the original and heat-treated fibers were calculated from elemental constitutions and density by assuming that a repeat unit contains three carbon atoms in average. By the heat treatment in air the molecular weight increased up to about $11 \%$, and the molecular volume decreased up to about $17 \%$. The deference in densities between the acrylonitrile copolymer fibers heat-treated in air and in a silicone oil bath was small at initial periods of the heat treatments. This indicates that with the copolymer fibers the density change at initial periods of the heat treatment in air is mainly due to a volumetric shrinkage accompanied with the cyclization of nitrile side groups from initiation centers already present in the fibers. Polyacrylonitrile homopolymer fibers showed a distinctive retardation in the relation between density and heat treatment time. This retardation is attributed to the fact that the formation of initiation centers of the cyclization in homopolymer fibers is rate-determined by the diffusion of oxygen from the atmosphere into the fibers.

(Received March 11, 1982)

\section{1. 緒言}

アクリル絨維は影著な熱可塑性を有してかり，高温で 微小な張加により溶断したり，また䄉維相互が融着する ことがある。アクリル繊維から炭素繊維を製造する工程 においては，このような性質を改善するために，炭素化 を行なう前段階の姏理しして，絨維を空気中低温(200〜 $300^{\circ} \mathrm{C}$ ) で熱观理することが必要とされる。進藤りとよれば， あらかじか低温の空笑中で熱炕理したアクリル繊維を炭 素化する之，空気中で熱炕理老ほよ゙こざふかった場合よ

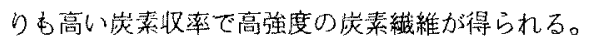

\footnotetext{
*現在の所嘱：豊田自䟚織機製作所

Present address: Toyoda Automatic Loom Works, Ltd, Toyoda-cho 2-1, Kariya, Aichi, Japan.
}

熱安定化㫡理によってもたらされる效果はGoodhew ら ${ }^{2)}$ の総説に述べられているように，ニトリル側基の付 加的重合によって部分的にはしで状上なったポリマが形 成されるととに基つくと考えられている。本報で述へる 熱安定化姏理とは，乙の空気中における熱処理を意昧す b。

アクリル繊維を空気中で熱安定化娃理すると構成元素 である水素の含有率が诚少するとともに酸素の含有率が 増大し ${ }^{3)}$ ，また室温におりる吸湿性が増大する。酸美含 有率”怙よび服湿率 る尺度上していちいられているようである。炭素䋐維製 造の諸プロ七ス条件之緎維性能の関連を求めるにおいて, 中間体である熱安定化紻維について熱安定化の程度をた んらかの尺度でとらえる必要がある，熱安定化の過程で 
生じていると考えられる複雑な化学的変化の詳細とは別 に，比較的測定の容易な特性值に熱安定化の尺度を求如 る事は重要である。

炭菜緁維製造に用いられるアクリル繊維の密度は 1.18 $\mathrm{g} / \mathrm{cm}^{3}$ 程度である。一方，炭素絨維の密度は $1.77 \sim 1.86$ $\mathrm{g} / \mathrm{cm}^{3}$ 程度の值を有している。すなわち炭素縅維の形成 過程で密度はいちじるしく変化する。密度の变化は炭素

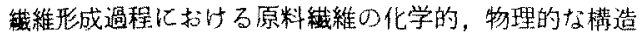
変化を反映しているはずである。琎って密度は炭素瀻維 を製造するための各姏理段階での構造变化をとらそる一 つの指標になりうる可能性がある。

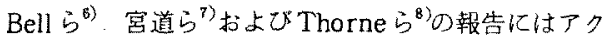
リル絨維の密度が空気中に括りる熱安定化の段階に书い てあ変化することが示されている。熱安定化処理に上っ て原料アクリル䄉維の元美構成が变化するととから，密 度変化には美構成の変化上体皘变化のそれぞれの寄与 があると推定される。本検討ではアクリル緎維の熱安定 化処理に関し，密度変化之熱安定化処理条件上の関連， およひ密度変化と元粰構成および体積变化との関連につ いて検討した。

\section{2. 实験方法}

\section{1 試 料}

本検討で主に用いた試料はアクリル酸エステルを主な コモイマとするてクリロニトリル共重合体縅維であり， また熱安定化の速度を高力る性能が付与されている。こ の試料はつィラメント系状であって，系の線密度は161 tex, 構成䄉維数は 1000 本でちる。nーヘプタン〜四湓 化炭素密度勾配管により $25^{\circ} \mathrm{C}$ で测定した密度は $1.18 \mathrm{~g} /$ $\mathrm{cm}^{3}$ であった。また試料の元素分析值は次のごとくで あった：C, 67.2；N, 24.9; H, 5.9；O， 20.

比較のために一部の実験にDralon T100 フィラメント糸(Bayer AG)を古ちい た。系の椿成䄉維数は 384 本である。本 試料はポリアクリロニトリルホもポリマ 加成䓃9，入手したDralon T-100を 自由状態で沸水中にて30 分間洗浄処理 してから寒験に供した。沸水処理後の系 の線密度は $812 \mathrm{~d}$ tex，密度は $1.17 \mathrm{~g} / \mathrm{cm}^{3}$ であった。

\section{2 熱安定化処理}

空気中での熱观理は，試料を巻きわく に緊镸状態で固定し，熱風得璪炣（八島 製作所，P-3B型，炣内舅度は土 $1^{\circ} \mathrm{C}$ の 精度で制御)によって行った。
一部の武料は空気中の酸㨞に蝺れない状態で熱処理さ れた。との目的の熱㚾理は卷きわくに緊張状態で圆定し た試料老所定の溜度 $\left( \pm 0.5^{\circ} \mathrm{C}\right.$ の精度で調節 $)$ のシリコーン 油中に真接漫漬することにより行った。所定の時間熱好 理した試料を室温のシリコーン油中に移しで冷却した。 ついで四塩化炭素をもちいて試料を洗浄し，以降の測定 に供した。

\section{3 測 定}

試料の密度は密度勾配管により $25^{\circ} \mathrm{Cで}$ て測定した。密度 勾配液として密度範囲が約 $1.10 \sim 1.50 \mathrm{~g} / \mathrm{cm}^{3}$ の測定には

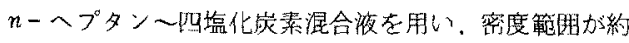
$1.50 \sim 1.60 \mathrm{~g} / \mathrm{cm}^{3}$ の测定には $n$ ープタン〜阳監化炭素 〜二臭化エチレン混合腹を用いた。

元素分析には柳本 CHNコーダー，MT-2型（柳本製作 所)在用いた。炭素、水素㧍よび窒素を定量し，残分を 酸琹しして算出しだ。

\section{3. 結果および考察}

\section{1 熱処理による密度および元素構成の変化}

アクリロニトリルコポリマ瀻維を種々の混度の空気中 で熱処理した場合の密度変化を熱処理時間の関数として

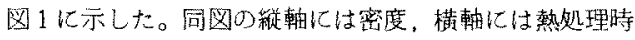
間を対数で表わした。いずれの温度で好理した場合も密 度之刘数熱処理時間の関係はS字型の曲線で表わされ， 莀時間の熱妈理では密度が約 $1.58 \mathrm{~g} / \mathrm{cm}^{3}$ の一定值上なる 傾问にある。また S字型曲線は混度が低いときに長時間 側に位置し，温度加高くなるにつれて短時間側飞移行し ている。このととから密度の熱処理による变化はある速 度過程であることが示晙される。

空気中でコポリマ瀻維老 $221 ， 252$ 拈よび $281^{\circ} \mathrm{C}$ で㮔

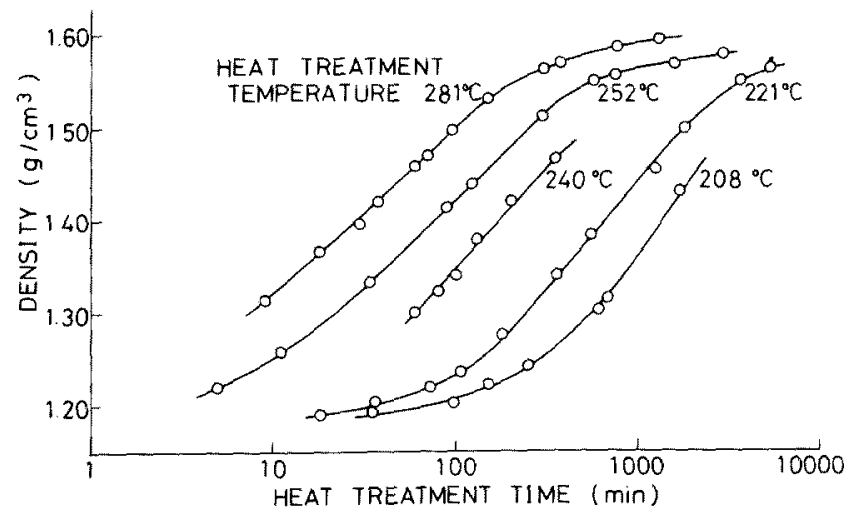

Fig. 1. Variation of density with heat treatment time for acrylonitrile copolymer fibers heattreated in air at five temperatures as indicated. 
程の時間熱処理した試料について元蔡分析を行った。元 素分析の結果に基ついて炭素原子1ケ当りの水素，窒瑟

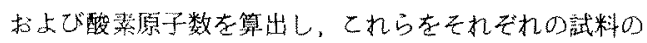
密度に対してプロットしたのが図 2 である。密度が高く なるはど、すな和熱好理時間が長いはど氷素原子数比 $(\mathrm{H} / \mathrm{C})$ 1減少し，酸素原子数比 $(\mathrm{O} / \mathrm{C})$ は增加している。 一万空素原子数比 $(\mathrm{N} / \mathrm{C})$ は密腐に上ってはとんど変化

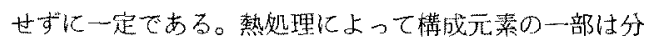
解生成ガスとして失われる。本检討では密度が 1.562 $\mathrm{g} / \mathrm{cm}^{3}$ よなるまで $252^{\circ} \mathrm{C} て ゙$ 熱炕理した試料では約 $14.5 \%$ の重量損失を測定した。窒菜原子数比 (N/C)が熱观理 によってはば一定であるととは，Standage ら ${ }^{10}$ 加指摘 しているようにガス体しして消失する分解物加ポリアク リロニトリル繰り返し単位を単位として生成することを 意味している。

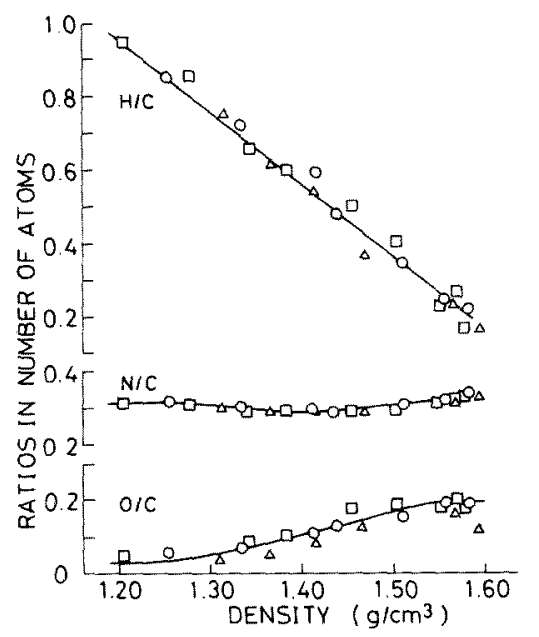

Fig. 2. Plots of atomic ratios against density for acrylonitrile copolymer fibers heat-treated in air. Heat treatment temperature $\left({ }^{\circ} \mathrm{C}\right)$ :

() $221,(0) 252,(\triangle) 281$.

四 2 が示す吕うに各原子数比之密度の関係は熱処理温 度にかかわらずほほ一㼁的な対応関㐿にあるとみてよい であるう。図2の関係から熱処理試料の密度を知れば， その武料の古よその元丵構成比を推定するととが可能で ある。

$\mathrm{Gill}^{11)}$ は炭素繊維を製造するに適当な熱安定化观理つ クリル繊維の酸素含有率は8１0\%の範用である上述へ ている。図3は酸素含有率を密度に対してプロットした あのである。Gill が述心る酸弯含有率籍圈は約 $1.4 \mathrm{~g} / \mathrm{cm}^{3}$ の密度域に相哓している。

\section{2 熱好理による䅡量および体皘変化}

原試料および熱炕理試料は平匀して繰り返し単位当り

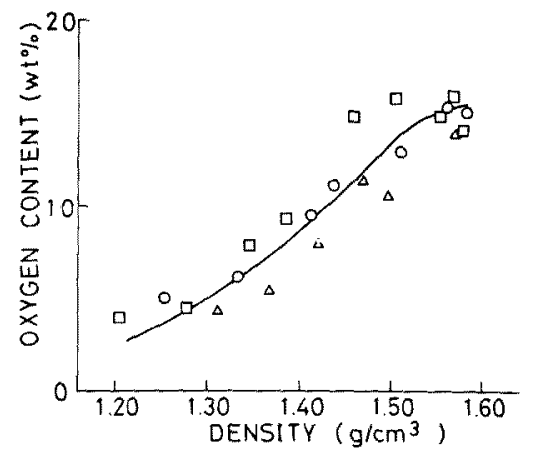

Fig. 3. Plot of oxygen content against density for acrylonitrile copolymer fibers heat-treated in air. Heat treatment temperature $\left({ }^{\circ} \mathrm{C}\right)$ :

(口) 221, (O) $252,(\triangle) 281$.

に3ケの炭素原子を有するとみなすと，元菜分析値加ら 繰り返し筆位当りの分子量，および分子量を密度て除す ることに上って繰り返し単位当りの分子体皘が求められ る。熱姏理したコポリマ繊維の絽り返し単位当りの分子 舅 $(M)$ を末熱処理䋞維のそれ $\left(M_{0}\right)$ 亿対する比 $\left(M / M_{0}\right)$ として求か，その結果を密度に対してプロットしたのが 图 4 である。繰り返し帮位当りの分子量は密度の高い試 料ほよ゙大टなる傾向仙ある。繰り返し単估当りの分子量 が熱姏理によって增大するのは，熱処理によりポ請銷 が水素を放出し，代って酸素を取り込むことによる。図 4 に上れ证 $M / M_{0}$ の密度に対する增加率は密度約 $1.40 \mathrm{~g}$ $/ \mathrm{cm}^{3}$ を境として，低密度側上りも高密度側で比較的太 上なる傾问がある。

図５に恃熱処理を行なったコポリマ瀻維の絽り返し単 位当 00 分于体積 $(V)$ 上未熱処理䋞維の民れ $\left(V_{0}\right)$ の比 $(V$ $\left./ V_{0}\right)$ を密度に対してプロットしてある。密度が高い試料

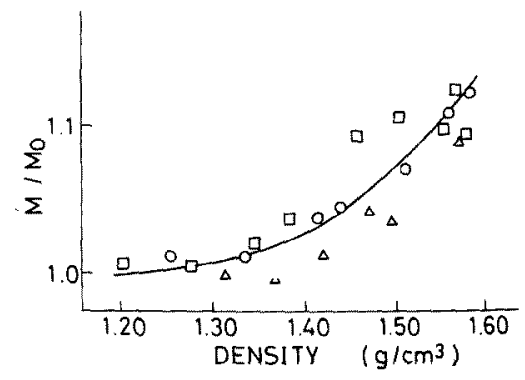

Fig. 4. Plot of relative molecular weight per repeat unit $\left(M / M_{0}\right)$ against density for acrylonitrile copolymer fibers heat-treated in air, where $M$ and $M_{0}$ denote the molecular weights per repeat unit for the heat-treated and original fibers, respectively. Heat treatment temperature $\left({ }^{\circ} \mathrm{C}\right):$ (口) $221,(\bigcirc) 252,(\triangle) 281$. 


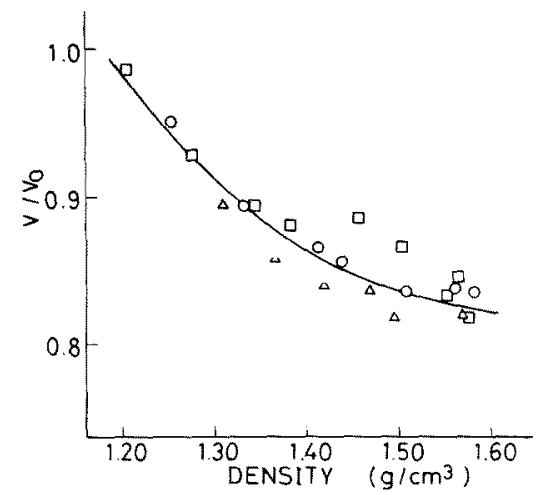

Fig. 5. Plot of relative molecular volume $\left(V / V_{0}\right)$ against density for acrylonitrile copolymer fibers heat-treated in air, where $V$ and $V_{0}$ denote the molecular volumes per repeat unit for the heat-treated and original fibers, respectively. Heat treatment temperature $\left({ }^{\circ} \mathrm{C}\right)$ :

(ㅁ) $221,(\bigcirc) 252,(\triangle) 281$.

はど繰り这し算位当り分子体皘は堿少している。アクリ ル瀻維を熱処理すると，最終的に繰り返し単位当り0分 子量は約 $11 \%$ 增大し，一方，繰り返し単位当りの分子 体稓は約 $17 \%$ 減少する。その結果として密度は約 $34 \%$ 程度增大寸るといえる。すなわち、アクリル瀻維の熱安 定化观理に上る密度增加は，熱処理に上って軽し原子で ある水素が放出されて重たい原子である酸素が取り込ま れることのみに园るのではなく，熱変成された分子鎖が 元の分子鎖よりも体積を収綰し，立てんされた構造とな ることに因る。

延伸アクリル䋘維のX線回折には赤道方向の $17^{\circ}$ に立 な反射， $29.5^{\circ}$ 近傍汇弱い反射が観測される。これらの 反射は熱安定化好理により稌々に消矢し，加っって赤道 方向の $255^{\circ}$ 近辺に新たな反射が現われる。この $255^{\circ}$ 近 辺の反射は，熱安定化の段階ではかなり散乱しているが， 炭素化の段階で加り鋭くなり，乱屡構造炭素に特有な 反射江变化する。このととから，宮道ら ${ }^{12)}$ は熱安定化戛 理されたアクリル織維では、ニトリル基の付加的重台に よって形成される平面的な環状セグメントが黑鉛網面と

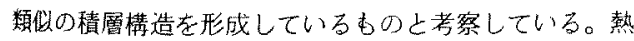
処理にともなう体積収縮は，乙の処理によって形成され

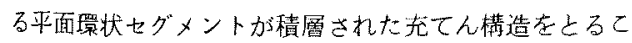
しに起因すると推定される。

3.3 ポリアクリロニトリル纎維の密度変化 ポリアクリロニトリルホモポりマ䋐維在 $252^{\circ} \mathrm{C} の$ 空気 中で種々の時間熱姏理したときの密度と熱処理時間の関绿 は图6に示すどとくである。なお同図の熱好理時間は線 型時間軸に目盛ってある。同図には，図1に示したコポ

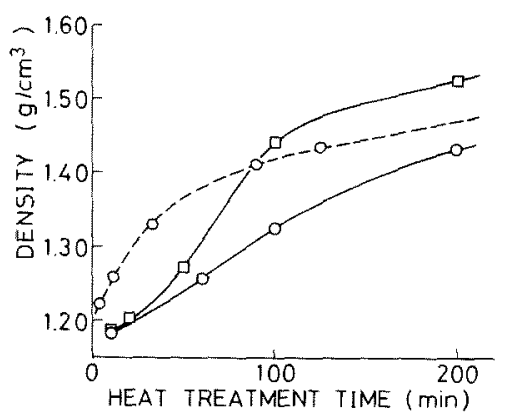

Fig. 6. Density changes of the polyacrylonitrile homopolymer and acrylonitrile copolymer fibers at relatively shorter times of heat treatment in air. Fibers: continuous line, polyacrylonitrile homopolymer fibers; broken line, acrylonitrile copolymer fibers.

Heat treatment temperature $\left({ }^{\circ} \mathrm{C}\right):$ (O) 252 , (口) 260 .

1) 繊維を $252^{\circ} \mathrm{C}$ で熱処理した場合の密度データの一部

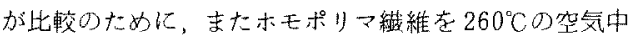
で種々の時間熱好理したときの密度が参考のたかにプロ ットされている。

ホモポリマ繊維とコポリマ䋐維を $252^{\circ} \mathrm{C}$ で特定の時間 熱処理したときの密度を比較すると，熱処理時間加比較

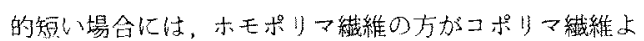

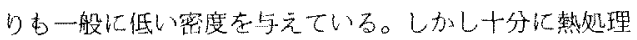

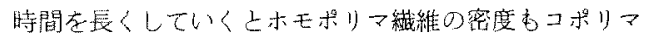

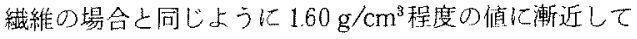
いくようであった。

コポリマ繊維に比較して，ホもポリマ緎維の熱処理に 上万密度変化の特徵は比較的熱姏理時間が短いところに みられる。すなわちコポりマ繊維の密度〜熱処理時間曲 線では，熱好理初期に曲線の接線の勾配すなわち密度の 変化速度が最大上なっている。そして知理時間が長くな るにつれて変化速度は笚調に減少している。てれに対し てホモポりマ䋐維では，最大の変化速度が現わ机るまで にある详れ時間が存在している。

アクリル繀維は熱安定化処理過程で処理時間か龙くな るにつ机て弾性率を增大し ${ }^{13)}$ ，あるいは長さ収縮を示す ことが知られている ${ }^{14\}}$ 。熱処理による弾性率変化扔上び 度ざ収縮はポリアクリロニトリルの璝化に基つく晲象と

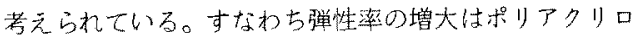
ニトリルの分子鎖が部分的に鲯化されたために：ミクロ ブラウン運動が㧕制されるととに基づくあのであり，ま

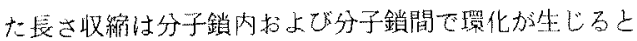
きの分子銷せグメント長ざの変化として院明されている 
嚳北は用始反応によって律速され，ポリアクリロニトリ

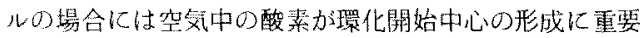

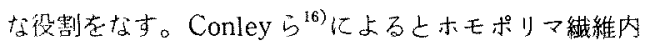
の開始中心は次りような過程にしたがって形成される。

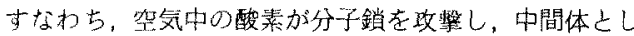
て過酸化物加形成され，乙心過酸化物中間体加分解する ととによって開始中心が形成される。アクリロニトリル コポリマの場合には，特にコポリマか酸基を含むとき， 酸基力開始反応を支配する ${ }^{17)}$

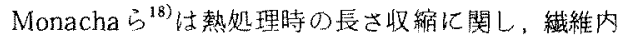
に既に開始中心を支つコポリマ纎維では熱処理開始時に 収繀速度が極大乞なり，絨維内にあらかじか開始中心の 存在しない木モ标りマ織維では収編一熱如理時間関係曲 線に遅れ時間が覞われることを報告している。同様に弾 性率の変化についてもコポリマ繊維では弾性率の増加速

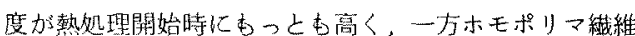
は增加速度加極大となるまでに時間的な遅札を示すとと 加認的ら㣗ているそして木モポリマ䋐維の弾性率一熱 処理時間閣係には，環化の開始中心の形成が空気中から 繊維内部への酸素の拡散に律速されるとして導出された 分程式が良く適合する ${ }^{19)}$ 。

ホモポリマ瀻維の密度変化に眭間的な遅れが現われる

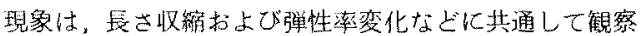
される悓象である。すなわちとの洋扎現象は密度增加を もたらす骤状構造の生成過程が空㞿中から瀻維内部人の 酸菜の搪散過程に律速されているととに基づいていると 部云石。

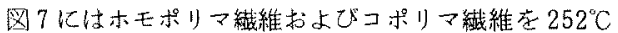
のシリコーン油中で熱好理したときの密度変化が，それ ぞれの繊維を同じ湿度の空気中で熱処理したときの滵度 变化し比較して示してある。同四に明ら加なよに，コ ポリマ繊維では、シリコーン伯中で熱処理した場合，す

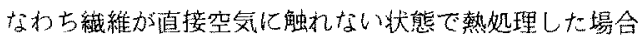
においても熱処理時間が比較的短い場合には空気中で熱 好理した場合と同じ样な密度变化老示している。このと

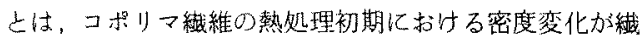
維に既に内在している開始中心に基つく睟化に律速され ているととを意味している。また熱処理初期に执いては 䋐維加驾気中加ら酸素を取り远むてとによる質量增加が 密度の增加に及ぼす勃果は，䇺化に基つく体積収縮效果 に比較して小さいてとが知られる。一方，木モポリマ緎 維では筀気中から繊維内人の酸素の㧒散に環化反応が律 脨されるために，熱処理時に䋐維が空気に触れているか いないか似って密度变化に大きな差加現われている。

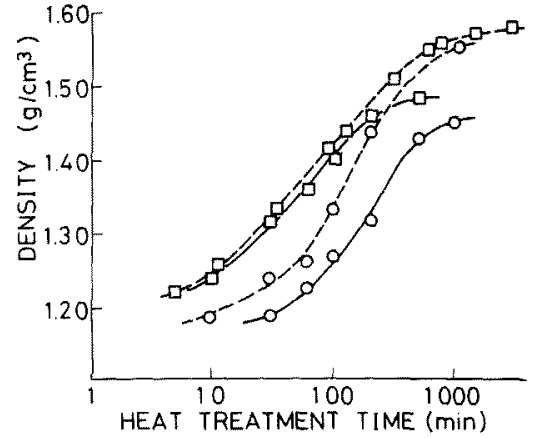

Fig. 7. Density changes of the polyacrylonitrile homopolymer and acrylonitrile copolymer fibers heat-treated at $252^{\circ} \mathrm{C}$ in a silicone oil bath, shown in comparison with the density changes of those fibers heat-treated at the same temperature in air: continuous line, heat-treated in a silicone oil bath; broken line, heat-treated in air; (O) polyacrylonitrile homopolymer fibers; (D) acrylonitrile copolymer fibers.

\section{4 密度変化に及ぼす熱好理温度および時間の 影響}

コポリマ瀻維の熱安定化過程における弾性率変化は 1 次機構に対応する契験式で良〈近似される ${ }^{13)}$ 。また赤外 吸収スペクトルの $2240 \mathrm{~cm}^{-1}$ に見られるニトリル基の吸 取与，熱安定化姏理に上り1次機構に対応する形式て変

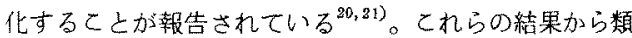
推するならば， $\rho_{t}$ を熱処理時間 $t$ における密度， $\rho_{0}$ お よび $\rho_{\mathrm{s}}$ それぞれ未姏理执よび十分長時間熱好理した縕 維の密度， $k$ 在熱処理温度のみに依存する係数として， 密度と熱処理時間の関係を次式で近似することが考えら れる。

$$
\frac{\rho_{t}-\rho_{0}}{\rho_{\mathrm{s}}-\rho_{0}}=1-\exp (-k t)
$$

密度変化が $(1)$ 式に従うならば, $\log \left\{\left(\rho_{\mathrm{s}}-\rho_{t}\right) /\left(\rho_{\mathrm{s}}-\rho_{0}\right)\right\}$ を処理時間 $t$ に対してプロットしたグラフは直線となる はずである。そこで一例として，空気中 $221^{\circ} \mathrm{C} て ゙$ 熱処理 したときの密度データについて， $\rho_{0}=1.18$ および $\rho_{s}=$ $1.58\left(\mathrm{~g} / \mathrm{cm}^{3}\right) \perp し, \log \left\{\left(\rho_{\mathrm{s}}-\rho_{t}\right) /\left(\rho_{\mathrm{s}}-\rho_{0}\right)\right\} \sim t$ 関係線 图を描いた結果は図8のでとくである。同図に明らかな 上うに密度変化の全域を(1)式で近似することは困難で あって，密度と熱処理時間の関係儿は弾性率変化あるい はニトリル基の赤外吸光度の変化に認められているよう な単純な規則性が見山されない。しかし图80曲線を形 式的にニつの1次機構の和で近优するととは可能であっ て，このような取り扱いを行うと図的な方法により下記 の実騟式が得られる。 


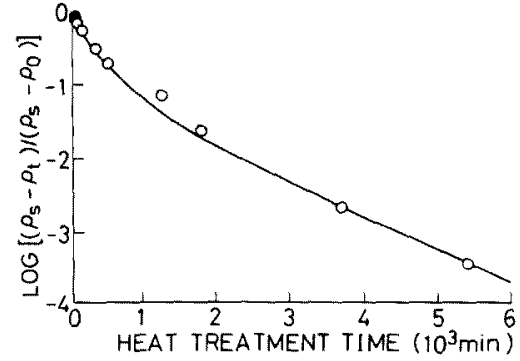

Fig. 8 Replot of the density data shown in Fig. 1 for acrylonitrile copolymer fibers heat-treated at $221^{\circ} \mathrm{C}$ in the form of $\log \left(\left(\rho_{s}-\rho_{t}\right) /\left(\rho_{s}-\rho_{0}\right)\right]$ against heat treatment time, where $\rho_{t}$ is density at a heat treatment time $t$, and $\rho_{0}$ $\left(=1.18 \mathrm{~g} / \mathrm{cm}^{3}\right)$ and $\rho_{\mathrm{s}}\left(=1.58 \mathrm{~g} / \mathrm{cm}^{3}\right)$ are the initial and final densities, respectively. Points indicate experimental values, and the continuous line represents the calculated curve from the experimental equation, $\left(\rho_{\mathrm{s}}-\rho_{t}\right) /\left(\rho_{\mathrm{s}}-\rho_{0}\right)$ $=C_{1} \exp \left(-k_{1} t\right)+C_{2} \exp \left(-k_{2} t\right)$, where $C_{1}=0.65$. $C_{2}=0.35, k_{1}=2.09 \times 10^{-8}\left(\mathrm{~min}^{-1}\right)$ and $k_{2}=4.39$ $\times 10^{-4}\left(\min ^{-1}\right)$.

$$
\begin{aligned}
\frac{\rho_{\mathrm{s}}-\rho_{t}}{\rho_{\mathrm{s}}-\rho_{0}}= & 0.65 \exp \left(-2.09 \times 10^{-3} t\right) \\
& +0.35 \exp \left(-4.39 \times 10^{-4} t\right)
\end{aligned}
$$

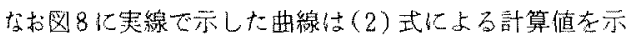
している。

密度の変化は弾性率変化あるいは二トリル基に上る赤 外吸光度の变化に比較して䔩純でない。しれは密度变化

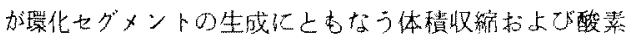
の取り入みによる質量增加などによって同時に影響され ていることによると考えられる。一年，例えば弾性湾変 北に関してみるならば，弾性率には環化に上る市銷の剛

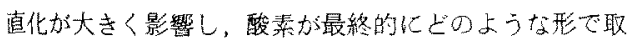

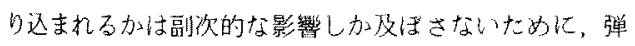

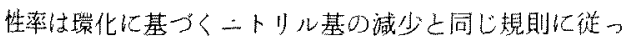
て変化すると考えられる。ちなみに䒠駼式 (2)で比較的 短侍間側の变化老律速する速度定数 $2.09 \times 10^{-3} \mathrm{~min}^{-1}$ は， 同様の温度での弾性率変化の速度定数 ${ }^{13)} 2.70 \times 10^{-3} \mathrm{~min}^{-1}$ と同程度であって。このととは熱姏理初期におりる密度

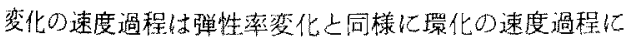
㑈存していることを意沬していると言えよう。

種々の熱処理温度での密度变化(四1)を詳紐に比較す ると，低密度領域(ないしは比較的短時間側)における密 度一熱炕理時間関係々，高密度領域(ないしは此較的長 時間側)でのそとは温度に上って異なるようてあって， 密度に関する熱好理湿度一時間換算関係は果純でない己
とが兒出される。このこと住密度変化に関与する複数の 速度過程が それぞれ暴なる活性化エネルギをむってい るととを意味している。また，このととから熱処理縄維 の密度が同じようであっても，熱观理濉度および時間の

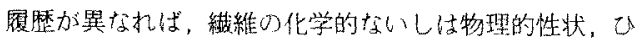

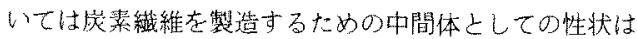
異なることが予想される。しかしながら，図2に胃られ 万ように元策棈成比上密度はほほ一義的な対応関係にあ るよみなせるのだ，この意味で空気中で熱安定化好理さ れた㵶維の熱桨成の程度を栖価する一つ0尺度上して密 度をもちいるこしは十分に可能でるう。

\section{4. 結論}

アクリル䄉維の熱安定化狆理による密度变化について 检部し，以下O結果老得た。

アクリル㵶維を空気中で熱湕理すると熱好理温度およ び熱処理時閻に応じて密度は增大し，段時間の熱処理に 上り約 $1.58 \sim 1.60 \mathrm{~g} / \mathrm{cm}^{3}$ の一定值に潮近する。密度変化

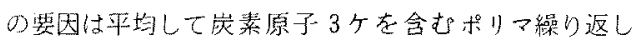

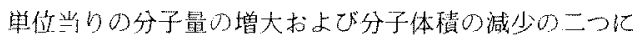

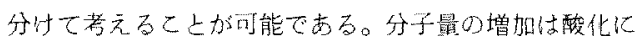

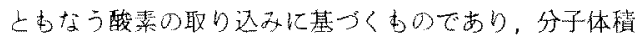
の減少は二トリ几側基の付扣的重合に上る環化七グメン トの生成にしもなうあの上言えよう。熱処理副程での弾

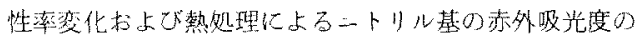

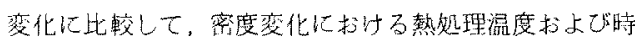
間依存性は策純ではない。これは弾性率执よびニトリル

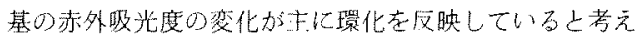
ら机るのに対し，密度变化には珤化上酸化の雨者加反胦

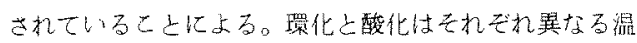
度倿存性をもつ速度過程に徉うと予想され，またこのこ

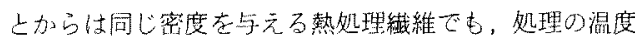
・時閪条倠が異なれ代化学的構造は必ずしも同一ではな け可能性が考えられる。しかし熱処理緎維について，炭

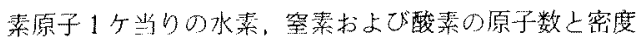
の間には，大略，一義的な対応関係が兒出されるので， 繁变成の平均的な度合を評価する一つの尺度上して密度 老ちいるこ上はある程度可能である。

\section{文献}

1) A. Shindo, Rept. Gov. Ind. Res., Osaka, No. 317 (1961).

2) R. P. Goodhew, A. J. Clarke and J. E. Bailey, Mater. Sci. Eng., 17, 3 (1975).

3) A.J. Clarke and J.E. Bailey, Nature, 243, 146 (1973).

4) U.S.P., 3, 539, 295. 
5) 特開昭 49-81626, 特公昭 51-25487.

6) J.W. Bell and R. K. Mulchandai, J. Soc. Dyers and Colour., 81, 55 (1965).

7) 宮道一大，为藤豊，片山将道，瀻学誌，23， 239 (1967).

8) D. J. Thorne and J. R. Marjoram, J. Appl. Polm. Sci, 16, 1357 (1972).

9) Standard-Delivery Programme, Bayer AG, May (1977).

10) A. E. Standage and R. D. Matkowsky, Eur. Polym. J., 7, 775 (1971).

11) R.M. Gill, "Carbon Fibres in Composite Materials", p. 50, published for The Plastics Institute, London (1972).

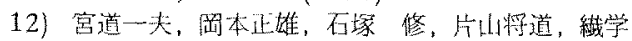
誌, 22, 538(1966).

13) A. Takaku, T. Kobayashi, S. Terui, N. Okui and J. Shimizu, Fibre Sct. Tech., 15, 87 (1981).
14) W. Watt and W. Johnson, Appl. Polym. Symposia, No. 9, 215 (1969).

15) D. J. Müller, E. Fitzer and A. K. Fiedler, International Conf. on Carbon Fibres, their Composites and Application, London (1971), Paper No. 2.

16) R.T. Conley and J.F. Bieron, J. Appl. Polym. Sci., 7, 1757 (1963).

17) N. Grassie and R. McGuchan, Eur. Polym, J., 8, 257 (1972).

18) L. M. Monacha and O. P. Bahl, Fibre Sci. Tech., 13, 199 (1980).

19) A. Takaku, S. Terui, C. Suzuki and J. Shimizu, Fibre Sci. Tech., 16, 237 (1982).

20) I. Noh and H. Yu, Polym. Lett., 4, 721 (1966).

21) K. Morita, H. Miyachi and T. Hiramatsu, Carbon, 19, 11 (1981). 